\title{
Analysis of the impact of fortified food consumption on overall dietary quality in Irish adults
}

\author{
Triona Joyce, Evelyn M. Hannon, Mairead Kiely and Albert Flynn* \\ Irish Universities Nutrition Alliance at the Department of Food and Nutritional Sciences, University College Cork, Cork, Republic \\ of Ireland \\ (Received 28 June 2007 - Revised 7 April 2008 - Accepted 15 April 2008 - First published online 17 July 2008)
}

The aim of the present study was to assess the impact of fortified food (FF) consumption on overall dietary quality in Irish adults. Data for this analysis was based on the North/South Ireland Food Consumption Survey which used a $7 \mathrm{~d}$ food diary to collect food and beverage intake data in a representative sample of 1379 Irish adults (662 men and 717 women) aged 18-64 years. Foods contained in the database that are fortified were identified from the presence of vitamins and/or minerals in the ingredient list on the label. The results showed that an increased level of FF consumption was associated with lower intakes (percentage food energy) of total fat and saturated fat (women only) and higher intakes of total carbohydrate, total sugars (but not added sugars) and starch. Increased consumption was associated with a more micronutrient-dense diet and a reduced prevalence of dietary inadequacies of $\mathrm{Ca}$, Fe, riboflavin and folate, particularly in women. Higher FF consumption was associated with higher intakes of fruit, lower intakes of alcohol and a lower likelihood of smoking in men and women. Thus it appears that FF consumption is a marker of both better dietary quality and healthy lifestyle behaviours.

Fortified foods: Macronutrient intakes: Dietary recommendations: Micronutrient adequacy

In Ireland and in the UK, the voluntary addition of vitamins and minerals to foods has been permitted for many years and a significant number of foods and beverages are now fortified ${ }^{(1-3)}$. However, practices of voluntary fortification vary widely among European Union countries, partly due to different regulatory environments. A European regulation on the addition of vitamins and minerals to foods has been adopted which harmonises legislation throughout member states of the European Union $^{(4)}$. This has stimulated a wide-ranging debate on the benefits and possible risks of voluntary fortification.

Studies in Ireland ${ }^{(5,6)}$, Germany ${ }^{(7)}$ and in the $\mathrm{USA}^{(8)}$ have shown that voluntary fortification of foods makes an important contribution to adequacy of micronutrient intakes in these countries. Addition of micronutrients to fortified ready-to-eat breakfast cereals (RTEBC) has been reported to contribute significantly to the intakes of several micronutrients in different population groups in a number of countries ${ }^{(9-16)}$. A number of studies have also shown an association between fortified breakfast cereal consumption and replacement of food energy from fat with food energy from carbohydrate in adults $^{(16-19)}$ and adolescents and children ${ }^{(9,12-15,20)}$. Some studies have shown that fortified breakfast cereal consumption is associated with an increased fibre intake in both adults ${ }^{(18,19)}$ and adolescents ${ }^{(13)}$.

Concerns about the practice of food fortification have been raised in a number of papers. These concerns focus on the risk of excess intake of micronutrients ${ }^{(21-23)}$ and on a possible adverse effect on overall dietary quality ${ }^{(22,23)}$. We have previously reported that the small proportions of fortified food (FF) consumers $(0 \cdot 1-2 \cdot 2 \%)$ who had mean daily intakes (MDI) of folic acid, vitamin $\mathrm{B}_{6}$, retinol, $\mathrm{Ca}, \mathrm{Zn}$ and vitamin $\mathrm{E}$ that exceeded the tolerable upper intake level was mainly due to nutritional supplements and was not affected by fortification ${ }^{(6)}$.

The aim of the present study was to assess the impact of level of FF consumption on overall dietary quality among Irish adults.

\section{Methods}

The food consumption and nutrient intake database

This analysis was performed using data from the North/South Ireland Food Consumption Survey ${ }^{(24,25)}$, which collected food intake data in a representative sample of 1379 adults aged 18-64 years (662 men and 717 women) in the Republic of Ireland and Northern Ireland from 1997 to 1999. Pregnant and lactating women were excluded. A $7 \mathrm{~d}$ estimated food diary was used to measure food intake and a database of habitual food and drink consumption was established. A more detailed account of the methodology of the survey ${ }^{(26)}$ and the sampling procedure ${ }^{(27)}$ is provided elsewhere.

Food records were analysed using WISP ${ }^{\odot}$ (Tinuviel Software, Llanfechell, Anglesey, UK). WISP $^{\odot}$ uses McCance 
and Widdowson's Composition of Foods 5th Edition ${ }^{(28)}$ and supplemental volumes ${ }^{(29-37)}$ as a food and nutrient database, along with additional data (including analysed recipes of composite dishes, manufacturers' data on generic Irish foods, new products that were commonly consumed and nutritional supplements) to determine nutrient intakes. The data handling, processing and quality-control procedures used in the construction of the food consumption and nutrient intake database have been described in detail elsewhere ${ }^{(26)}$.

\section{Identification of fortified foods}

Foods contained in the database that are fortified were identified from the presence of vitamins and/or minerals in the ingredient list on the label. For the purposes of this paper 'fortification' refers to the voluntary addition of micronutrients by food manufacturers, which is identified in product labelling and excludes (semi) mandatory addition of micronutrients to foods (for example, vitamins $\mathrm{A}$ and $\mathrm{D}$ to fat spreads and low-fat milk) to ensure 'nutritional equivalence' and vitamins and minerals added to flour for the purposes of 'restoration'. These are considered 'indigenous' for the purposes of this discussion. The nutrient composition data were revised for many FF (for example, many of the RTEBC) using up-to-date manufacturers' data. New FF were assigned new food codes with corresponding nutrient composition data from manufacturers.

Foods and beverages in the database that were fortified included RTEBC, fruit juices, squashes and cordials, carbonated beverages, milks, other beverages, breads, non-chocolate confectionery, savouries and miscellaneous foods.

The food consumption database generated from the survey listed each individual food item as consumed by each respondent, together with the nutrient composition for the quantity of each food consumed. Overall, 2914 different foods (as well as 146 nutritional supplements) were recorded as consumed, fifty-four of which were FF. Respondents who consumed a FF at any time during the $7 \mathrm{~d}$ of recording were classified as FF consumers. Tertile analysis was used to divide men and women separately into low, medium and high consumers of $\mathrm{FF}$ on the basis of mean daily energy intake from FF.

\section{Socio-demographic, and health and lifestyle characteristics}

Self-administered questionnaire data were obtained on sociodemographic factors and health and lifestyle parameters. The division of the sample into social class groups was based on the respondents' occupation (including last main occupation for those not working or retired) or, if the respondent was not the head, the head of household's occupation. All subjects were classified according to the Central Statistics Office, Census 96 Occupations ${ }^{(38)}$.

Nutritional supplement consumption was recorded by the respondent in the $7 \mathrm{~d}$ food diary. Respondents who consumed a supplement at any time during the $7 \mathrm{~d}$ of recording were classified as supplement users.

\section{Definition of added sugars}

Added sugars are sugars and syrups that are added to foods during processing or preparation ${ }^{(39)}$.

\section{Comparison with dietary recommendations}

The percentage of individuals exceeding the maximum recommended alcohol units per week (men twenty-one units; women fourteen units) ${ }^{(40)}$ was also calculated.

\section{Adequacy of micronutrient intakes}

The method of assessing adequacy of micronutrient intakes using the average requirement ( $\mathrm{AR}$ ) has been described in detail in the study by Hannon et al. ${ }^{(6)}$.

\section{Under-reporting of food intake}

As with any dietary survey where food intake is self-reported there is evidence of misreporting, in particular, under-reporting, in this survey ${ }^{(41)}$. The prevalence of inadequate intake of nutrients was calculated both including and excluding underreporters of energy intake, identified as having an energy intake:BMR ratio of less than $1 \cdot 05^{(42)}$. Under-reporting leads to an overestimate of the prevalence of inadequate intakes. The analysis in the present study was carried out both including and excluding under-reporters of energy intake. The percentage of under-reporters ( $20 \%$ of total sample) was higher in nonconsumers ( $20 \%$ in men and $28 \%$ in women) than in consumers of FF (13\% in men and $22 \%$ in women). The prevalence of under-reporting was similar across the different levels of FF intake. The data presented includes under-reporters, as removal of under-reporters did not change the overall results observed in the association of FF consumption with intakes or adequacy of micronutrients, or intakes of macronutrients, fibre and fruit and vegetables.

\section{Statistical analysis}

Data were analysed using SPSS ${ }^{\circledR}$ version 14.0 for Windows ${ }^{\mathrm{TM}}$ (SPSS Inc., Chicago, IL, USA). Tertile analysis was used to divide men and women separately into low, medium and high consumers of FF. To assess associations between percentages of non-, low, medium and high consumers of FF in different categories, $\chi^{2}$ analysis and Pearson's $\chi^{2}$ were used. One-way ANOVA with post hoc multiple comparisons was used to determine significant differences in means between types of FF consumers.

\section{Results}

Overall, $66 \%$ of individuals ( $65 \%$ of men and $68 \%$ of women) were consumers of FF. Mean daily energy intake from FF (MJ and percentage total energy) was $0.13 \mathrm{MJ} / 1.3 \%$ (low), $0.35 \mathrm{MJ} / 3.6 \%$ (medium) and $0.83 \mathrm{MJ} / 7.0 \%$ (high) in men, and $0.11 \mathrm{MJ} / 1.4 \%$ (low), $0.31 \mathrm{MJ} / 4.3 \%$ (medium) and $0.72 \mathrm{MJ} /$ $9.3 \%$ (high) in women. In men and women there was a higher proportion of 18- to 35-year-olds and a lower proportion of 51- to 64-year-olds in the consumers of FF compared with non-consumers (Table 1). In the managerial, professional and technical social class there was a higher proportion among consumers than non-consumers, particularly in women (Table 1). For both men and women the percentage current smokers decreased and the percentage non-smokers increased with increasing consumption of FF. Supplement use tended to 
Table 1. Distribution of subjects (\%) in fortified food consumption categories by age group, social class, smoking status and prevalence of supplement use

\begin{tabular}{|c|c|c|c|c|c|c|c|c|c|c|}
\hline \multirow[b]{2}{*}{ Consumer categories... } & \multicolumn{4}{|c|}{ Men } & \multirow[b]{2}{*}{$P$} & \multicolumn{4}{|c|}{ Women } & \multirow[b]{2}{*}{$P$} \\
\hline & Non & Low & Medium & High & & Non & Low & Medium & High & \\
\hline Subjects $(n)$ & 234 & 143 & 142 & 143 & & 232 & 161 & 162 & 162 & \\
\hline \multicolumn{11}{|l|}{ Age group (\%) } \\
\hline $18-35$ years & $29 \cdot 1^{a}$ & $43 \cdot 4^{b}$ & $43 \cdot 0^{b}$ & $43 \cdot 4^{b}$ & & $34.9^{a}$ & $39 \cdot 8^{b}$ & $43 \cdot 2^{b}$ & $33 \cdot 3^{a}$ & \\
\hline $36-50$ years & 35.9 & $35 \cdot 0$ & $33 \cdot 8$ & $37 \cdot 8$ & NS & $35 \cdot 3$ & $44 \cdot 1$ & $40 \cdot 7$ & 41.4 & NS \\
\hline $51-64$ years & $35 \cdot 0^{\mathrm{a}}$ & $21 \cdot 7^{b}$ & $23 \cdot 2^{b}$ & $18 \cdot 9^{b}$ & & $29 \cdot 7^{\mathrm{a}}$ & $16 \cdot 1^{\mathrm{b}}$ & $16 \cdot 0^{\mathrm{b}}$ & $25 \cdot 3^{a, b}$ & \\
\hline Managerial, professional and technical (\%) & 39.5 & $43 \cdot 3$ & $46 \cdot 6$ & $44 \cdot 1$ & NS & $39 \cdot 4^{a}$ & $45 \cdot 4^{a, b}$ & $50 \cdot 6^{b}$ & $46 \cdot 1^{\mathrm{b}}$ & \\
\hline Non-manual skilled (\%) & $11 \cdot 2$ & $14 \cdot 2$ & $15 \cdot 0$ & $19 \cdot 8$ & NS & $27 \cdot 2^{\mathrm{a}}$ & $21 \cdot 7^{\mathrm{a}, \mathrm{b}}$ & $17 \cdot 9^{b}$ & $27 \cdot 9^{a}$ & \\
\hline Manual skilled (\%) & $32 \cdot 3^{a}$ & $20 \cdot 1^{a, b}$ & $22 \cdot 6^{a, b}$ & $19 \cdot 1^{\mathrm{b}}$ & & $15 \cdot 5$ & $17 \cdot 1$ & $17 \cdot 9$ & $12 \cdot 3$ & NS \\
\hline Semi-skilled, unskilled (\%) & $17 \cdot 0$ & $22 \cdot 4$ & $15 \cdot 8$ & $16 \cdot 9$ & NS & $17 \cdot 8$ & $15 \cdot 8$ & 13.5 & $13 \cdot 6$ & NS \\
\hline Smoking status $(n)$ & 231 & 139 & 140 & 142 & & 230 & 159 & 160 & 160 & \\
\hline Current smoker (\%) & $39 \cdot 4^{\mathrm{a}}$ & $38 \cdot 1^{\mathrm{a}}$ & $31 \cdot 4^{\mathrm{a}}$ & $21 \cdot 1^{\mathrm{b}}$ & & $41 \cdot 7^{\mathrm{a}}$ & $34 \cdot 6^{\mathrm{a}}$ & $25 \cdot 6^{\mathrm{b}}$ & $22 \cdot 5^{\mathrm{b}}$ & \\
\hline Ex-smoker (\%) & $25 \cdot 5$ & $25 \cdot 9$ & $27 \cdot 1$ & $26 \cdot 8$ & NS & $22 \cdot 2$ & 23.9 & $23 \cdot 1$ & $20 \cdot 6$ & NS \\
\hline Non-smoker (\%) & $35 \cdot 1^{a}$ & $36 \cdot 0^{\mathrm{a}}$ & $41 \cdot 4^{a}$ & $52 \cdot 1^{\mathrm{b}}$ & & $36 \cdot 1^{a}$ & $41 \cdot 5^{\mathrm{a}, \mathrm{b}}$ & $51 \cdot 3^{\mathrm{b}, \mathrm{c}}$ & $56 \cdot 9^{c}$ & \\
\hline
\end{tabular}

NS, non-significant differences between categories of fortified food consumers in men and women.

$\mathrm{a}, \mathrm{b}, \mathrm{c}$ Values within a row with unlike superscript letters were significantly different between categories of fortified food consumers in men and women $(P<0.05)$.

increase in both men and women with increased consumption of FF but this increase was not significant (Table 1).

Table 2 presents mean daily energy and macronutrient intakes for men and women by tertile of energy intake from FF. In men, MDI of energy, protein, fat and carbohydrate (total sugars and starch) were significantly higher $(P<0.05)$ in high compared with non-, low and medium consumers. In women, mean daily energy and protein intakes were significantly higher $(P<0 \cdot 05)$ in high compared with non-consumers while for total carbohydrate, total sugars and starch, MDI were significantly higher in high compared with non-, low and medium consumers. When expressed as percentage food energy, total fat intake decreased, with a corresponding decrease in the intakes of saturated (women only), monounsaturated and polyunsaturated fats and intake of total carbohydrate, total sugars and starch increased with higher consumption of FF. In men and women mean daily alcohol intake was significantly higher $(P<0.05)$ in non-consumers compared with high consumers (Table 2 ).

In Table 3, MDI of NSP (g/d and g/MJ per d) are reported for both men and women by tertile of energy intake from FF. High consumers in men and women had significantly higher $(P<0.05)$ mean daily NSP $(\mathrm{g} / \mathrm{d})$ intakes than non-, low and medium consumers. In men and women nutrient density for NSP was highest among high consumers of FF (Table 3).

Table 4 presents mean daily fruit and vegetable intakes by sex and tertile of energy intake from FF. In men and women high consumers of FF had the highest intakes of fruit but there was no association of vegetable intake with level of FF consumption.

In Table 5, MDI of $\mathrm{Na}(\mathrm{g} / \mathrm{d}$ and $\mathrm{g} / \mathrm{MJ}$ per $\mathrm{d})$ and salt $(\mathrm{g} / \mathrm{d})$ and the percentage contribution of fortified foods to $\mathrm{Na}$ intakes are reported for both men and women by tertile of energy intake from FF. In men and women (except non-consumers in women), salt intake from food (excluding salt added in cooking and at the table) exceeds the recommendation for total salt $(6 \mathrm{~g})$. Salt and $\mathrm{Na}$ intake was significantly higher $(P<0.05)$ in high consumers of $\mathrm{FF}$ in comparison with non-consumers. The percentage contribution of fortified foods to $\mathrm{Na}$ intakes for the different $\mathrm{FF}$ groups ranged from 1.5 to $5.6 \%$ and significantly increased $(P<0.05)$ across the tertiles for both men and women. When adjusted for energy intake, $\mathrm{Na}$ intake was higher in high consumers than in nonconsumers of FF; however, Na intake did not increase with level of FF consumption.

In Table $6^{(40)}$, the percentage of Irish adults with intakes of alcohol below the recommended maximum intake levels by sex and tertile of energy intake from FF are reported. The percentage exceeding the recommended maximum level of alcohol was lower in high consumers than in non-consumers of FF (men only) but there was no significant association with increasing consumption of FF.

In Table 7 mean daily micronutrient intakes per $10 \mathrm{MJ}$ total energy are reported for both men and women by tertile of energy intake from FF. With increasing consumption of FF, MDI (per $10 \mathrm{MJ}$ ) of $\mathrm{Ca}, \mathrm{Fe}$, riboflavin and folate increased in men and MDI (per $10 \mathrm{MJ}$ ) of $\mathrm{Ca}, \mathrm{Mg}, \mathrm{P}, \mathrm{Fe}$, niacin, vitamin $\mathrm{B}_{6}$ and folate increased in women (Table 7). Intakes of $\mathrm{Cu}$, thiamin, biotin, pantothenate, $\mathrm{Zn}$ and vitamins $\mathrm{A}, \mathrm{D}, \mathrm{E}, \mathrm{C}$ and $B_{12}$ were also analysed but there was no increase in intakes of these micronutrients as FF consumption increased.

Table $8^{(43)}$ presents the percentage of men and women with MDI of micronutrients below the average requirement (AR) by tertile of energy intake from FF. In men and women, the percentage with $\mathrm{MDI}$ of $\mathrm{Ca}, \mathrm{Fe}, \mathrm{Cu}, \mathrm{Zn}$, vitamin $\mathrm{A}$, riboflavin, folate and vitamin $\mathrm{C}$ below the $\mathrm{AR}$ decreased with increasing consumption of FF.

\section{Discussion}

The present study analysed the impact of FF consumption on nutrient intakes, compliance with the dietary recommendations for alcohol and adequacy of micronutrient intakes.

The results of this analysis show that an increasing consumption of FF was associated with a lower percentage of food energy intake from total fat, as well as SFA, MUFA 
Table 2. Daily energy and macronutrient intakes in Irish adults by sex and tertile of energy intake from fortified foods (Mean values and standard deviations)

\begin{tabular}{|c|c|c|c|c|c|c|c|c|c|c|c|c|c|c|c|c|}
\hline \multirow{3}{*}{$\begin{array}{l}\text { Consumer categories... } \\
\text { Nutrient }\end{array}$} & \multicolumn{8}{|c|}{ Men } & \multicolumn{8}{|c|}{ Women } \\
\hline & \multicolumn{2}{|c|}{ Non ( $n$ 234) } & \multicolumn{2}{|c|}{ Low ( $n$ 143) } & \multicolumn{2}{|c|}{ Medium ( $n$ 142) } & \multicolumn{2}{|c|}{ High ( $n$ 143) } & \multicolumn{2}{|c|}{ Non ( $n$ 232) } & \multicolumn{2}{|c|}{ Low $(n 161)$} & \multicolumn{2}{|c|}{ Medium ( $n$ 162) } & \multicolumn{2}{|c|}{ High ( $n$ 162) } \\
\hline & Mean & SD & Mean & SD & Mean & SD & Mean & SD & Mean & SD & Mean & SD & Mean & SD & Mean & SD \\
\hline Energy (MJ) & $10 \cdot 8^{\mathrm{a}}$ & 3.3 & $10 \cdot 7^{\mathrm{a}}$ & 2.9 & $10 \cdot 6^{\mathrm{a}}$ & $2 \cdot 8$ & $12 \cdot 3^{b}$ & 2.8 & $7.4^{a}$ & 1.9 & $7 \cdot 8^{a, b}$ & $2 \cdot 1$ & $7 \cdot 5^{\mathrm{a}, \mathrm{b}}$ & 1.9 & $8.1^{\mathrm{b}}$ & $2 \cdot 1$ \\
\hline Protein $(\mathrm{g})$ & $97 \cdot 8^{\mathrm{a}}$ & 25.5 & $98.5^{a}$ & 27.4 & $96 \cdot 3^{\mathrm{a}}$ & 23.8 & $109 \cdot 8^{\mathrm{b}}$ & 27.9 & $67 \cdot 1^{a}$ & $15 \cdot 6$ & $69 \cdot 5^{\mathrm{a}, \mathrm{b}}$ & 18.5 & $70 \cdot 1^{a, b}$ & $17 \cdot 7$ & $73 \cdot 6^{\mathrm{b}}$ & $17 \cdot 0$ \\
\hline Fat $(\mathrm{g})$ & $102 \cdot 4^{\mathrm{a}}$ & 36.8 & $99.5^{\mathrm{a}}$ & 31.4 & $96 \cdot 5^{\mathrm{a}}$ & 30.9 & $112 \cdot 7^{b}$ & 34.8 & 74.4 & 24.4 & 74.7 & 26.0 & 70.5 & 23.0 & 73.4 & 25.2 \\
\hline Carbohydrate (g) & $287 \cdot 6^{\mathrm{a}}$ & $96 \cdot 2$ & $287.8^{\mathrm{a}}$ & $95 \cdot 1$ & $296 \cdot 4^{\mathrm{a}}$ & $84 \cdot 1$ & $358.9^{b}$ & 88.5 & $201 \cdot 4^{\mathrm{a}}$ & $57 \cdot 1$ & $219 \cdot 3^{b}$ & 62.9 & $216 \cdot 7^{\mathrm{a}, \mathrm{b}}$ & 58.6 & $243.7^{c}$ & $64 \cdot 0$ \\
\hline Total sugars (g) & $105 \cdot 0^{\mathrm{a}}$ & 53.1 & $103.4^{\mathrm{a}}$ & 47.6 & $116 \cdot 1^{\mathrm{a}}$ & 44.7 & $133.8^{\mathrm{b}}$ & 50.5 & $77 \cdot 4^{\mathrm{a}}$ & 33.7 & $82 \cdot 3^{\mathrm{a}}$ & 35.0 & $84.5^{\mathrm{a}}$ & 31.9 & $97 \cdot 3^{\mathrm{b}}$ & 38.7 \\
\hline Added sugar (g) & 64.9 & 46.0 & $62 \cdot 8$ & 41.3 & 69.0 & 38.6 & 73.0 & 40.1 & $42 \cdot 0$ & $26 \cdot 9$ & $42 \cdot 8$ & 29.4 & 42.4 & $25 \cdot 1$ & 49.4 & $27 \cdot 6$ \\
\hline Starch $(\mathrm{g})$ & $178 \cdot 8^{a}$ & 60.4 & $180 \cdot 5^{\mathrm{a}}$ & 58.9 & $175 \cdot 9^{\mathrm{a}}$ & $50 \cdot 1$ & $221 \cdot 1^{\mathrm{b}}$ & 58.5 & $120 \cdot 5^{\mathrm{a}}$ & 33.1 & $132 \cdot 7^{\mathrm{a}}$ & $38 \cdot 3$ & $128.8^{\mathrm{a}}$ & 35.4 & $141.8^{\mathrm{b}}$ & $36 \cdot 3$ \\
\hline Alcohol (g) & $26 \cdot 5^{\mathrm{a}}$ & 33.7 & $23 \cdot 7^{\mathrm{a}, \mathrm{b}}$ & 29.6 & $21 \cdot 3^{a, b}$ & 25.5 & $17 \cdot 7^{b}$ & $26 \cdot 1$ & $10 \cdot 5^{\mathrm{a}}$ & 13.8 & $12 \cdot 3^{a, b}$ & $14 \cdot 2$ & $7 \cdot 6^{\mathrm{b}, \mathrm{c}}$ & 12.6 & $6.4^{c}$ & $9 \cdot 8$ \\
\hline Protein (\%FE) & $16 \cdot 8^{\mathrm{a}}$ & $2 \cdot 9$ & $16.9^{\mathrm{a}}$ & 3.1 & $16 \cdot 6^{a, b}$ & 2.8 & $15 \cdot 8^{\mathrm{b}}$ & 2.4 & $16 \cdot 3$ & 3.1 & 16.0 & $\begin{array}{r}14.2 \\
2.9\end{array}$ & 16.4 & 3.0 & $\begin{array}{r}0.4 \\
16 \cdot 1\end{array}$ & 2.9 \\
\hline Fat (\%FE) & $38.1^{a}$ & 5.6 & $37 \cdot 6^{a, b}$ & $5 \cdot 1$ & $36 \cdot 3^{\mathrm{b}}$ & $5 \cdot 3$ & $35 \cdot 8^{\mathrm{b}}$ & $5 \cdot 2$ & $39 \cdot 2^{a}$ & 5.8 & $37.4^{\mathrm{b}}$ & 5.9 & $36 \cdot 3^{b, c}$ & 5.6 & $34.7^{c}$ & 5.5 \\
\hline Saturated fat (\%FE) & 14.6 & 3.4 & 14.4 & 3.1 & 14.2 & 3.0 & 14.4 & 3.0 & $14.9^{a}$ & 3.4 & $14.5^{\mathrm{a}, \mathrm{b}}$ & 3.2 & $14 \cdot 0^{\mathrm{b}, \mathrm{c}}$ & 3.2 & $13.5^{\mathrm{c}}$ & 2.9 \\
\hline Monounsaturated fat (\%FE) & $13 \cdot 0^{\mathrm{a}}$ & $2 \cdot 2$ & $12 \cdot 9^{a, b}$ & $2 \cdot 0$ & $12 \cdot 3^{b, c}$ & $2 \cdot 1$ & $11.8^{\mathrm{C}}$ & 2.0 & $13 \cdot 1^{a}$ & $2 \cdot 3$ & $12 \cdot 3^{\mathrm{a}, \mathrm{b}}$ & $2 \cdot 2$ & $12 \cdot 0^{b, c}$ & 2.0 & $11.5^{\mathrm{c}}$ & $2 \cdot 2$ \\
\hline Polyunsaturated fat (\%FE) & $7 \cdot 4^{\mathrm{a}, \mathrm{b}}$ & 2.5 & $7.6^{\mathrm{a}}$ & $2 \cdot 0$ & $7 \cdot 0^{a, b}$ & 1.9 & $6 \cdot 8^{\mathrm{b}}$ & 2.0 & $8 \cdot 1^{\mathrm{a}}$ & 2.6 & $7.6^{\mathrm{a}}$ & $2 \cdot 2$ & $7.5^{\mathrm{a}, \mathrm{b}}$ & 2.0 & $6 \cdot 8^{\mathrm{b}}$ & $2 \cdot 1$ \\
\hline Carbohydrate (\%FE) & $45 \cdot 1^{\mathrm{a}}$ & 5.6 & $45 \cdot 4^{\mathrm{a}}$ & $5 \cdot 1$ & $47 \cdot 0^{\mathrm{c}}$ & 5.0 & $48 \cdot 1^{\mathrm{b}}$ & 5.2 & $44 \cdot 7^{\mathrm{a}}$ & $5 \cdot 3$ & $46 \cdot 6^{\mathrm{b}}$ & 5.7 & $47 \cdot 1^{\mathrm{b}}$ & $5 \cdot 2$ & $49 \cdot 0^{\mathrm{c}}$ & $5 \cdot 1$ \\
\hline Sugar (\%FE) & $16 \cdot 2^{\mathrm{a}}$ & 5.4 & $16 \cdot 0^{\mathrm{a}}$ & 4.7 & $18 \cdot 3^{\mathrm{b}}$ & 4.7 & $17 \cdot 7^{\mathrm{b}}$ & 5.1 & $16 \cdot 8^{a}$ & 5.5 & $17 \cdot 4^{\mathrm{a}}$ & 4.9 & $18 \cdot 2^{\mathrm{a}, \mathrm{b}}$ & 4.9 & $19 \cdot 3^{\mathrm{b}}$ & 4.9 \\
\hline Added sugar (\%FE) & 9.8 & $5 \cdot 1$ & 9.5 & 4.7 & $10 \cdot 7$ & 4.8 & 9.6 & 4.4 & 8.9 & 4.8 & $8 \cdot 8$ & 4.6 & 8.9 & 4.0 & 9.5 & 3.8 \\
\hline Starch (\%FE) & $28 \cdot 3^{a}$ & 5.5 & $28 \cdot 7^{a, b}$ & 4.6 & $28 \cdot 0^{\mathrm{a}, \mathrm{b}}$ & 4.1 & $29.8^{\mathrm{b}}$ & 5.4 & $27 \cdot 1^{a}$ & 4.9 & $28 \cdot 4^{a, b}$ & 4.9 & $28 \cdot 1^{a, b}$ & 4.5 & $28.8^{\mathrm{b}}$ & $5 \cdot 1$ \\
\hline
\end{tabular}

$\%$ FE, percentage food energy.

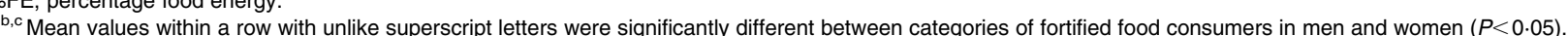


Table 3. Daily intake of NSP in Irish adults by sex and tertile of energy intake from fortified foods

(Mean values and standard deviations)

\begin{tabular}{|c|c|c|c|c|c|}
\hline \multirow{2}{*}{$\begin{array}{l}\text { Consumer } \\
\text { categories }\end{array}$} & \multirow{2}{*}{$\begin{array}{l}\text { Subjects } \\
(n)\end{array}$} & \multicolumn{2}{|c|}{$\operatorname{NSP}(g / d)$} & \multicolumn{2}{|c|}{$\begin{array}{l}\mathrm{NSP}(\mathrm{g} / 10 \mathrm{MJ} \\
\text { per } \mathrm{d})\end{array}$} \\
\hline & & Mean & SD & Mean & SD \\
\hline \multicolumn{6}{|l|}{ Men } \\
\hline Non & 234 & $16 \cdot 6^{a}$ & $6 \cdot 6$ & $15 \cdot 8^{a, b}$ & $6 \cdot 4$ \\
\hline Low & 143 & $15 \cdot 7^{a}$ & 5.9 & $15 \cdot 0^{a}$ & 4.5 \\
\hline Medium & 142 & $15 \cdot 9^{a}$ & $5 \cdot 8$ & $15 \cdot 5^{a, b}$ & 5.9 \\
\hline High & 143 & $20 \cdot 8^{b}$ & $8 \cdot 1$ & $17 \cdot 2^{\mathrm{b}}$ & $6 \cdot 3$ \\
\hline \multicolumn{6}{|l|}{ Women } \\
\hline Non & 232 & $11 \cdot 6^{a}$ & $4 \cdot 1$ & $16 \cdot 0^{\mathrm{a}}$ & $5 \cdot 1$ \\
\hline Low & 161 & $13 \cdot 2^{b}$ & 4.4 & $17 \cdot 4^{a, b}$ & $5 \cdot 6$ \\
\hline Medium & 162 & $13 \cdot 5^{b}$ & $4 \cdot 3$ & $18 \cdot 4^{\mathrm{b}, \mathrm{c}}$ & $5 \cdot 6$ \\
\hline High & 162 & $15 \cdot 9^{c}$ & 6.6 & $20 \cdot 1^{c}$ & 7.9 \\
\hline
\end{tabular}

${ }^{a, b, c}$ Mean values within a column with unlike superscript letters were significantly different between categories of fortified food consumers in men and women $(P<0.05)$.

and PUFA, and a higher percentage of food energy intake from total carbohydrate, as well as total sugars (but not added sugars) and starch.

While there are no studies that have examined the impact of overall consumption of FF on dietary quality with respect to macronutrients in adults, there are a number of such studies for fortified breakfast cereals. In the present study fortified breakfast cereals were the predominant category of fortified foods consumed. Approximately $72 \%$ of FF recorded in the present study were fortified breakfast cereals which contributed 3.8 and $4.8 \%$ of average energy intake in men and women consumers of FF, respectively, compared with the 3.9 and $5.0 \%$ of energy intake from all fortified foods ${ }^{(6)}$. The analysis of breakfast cereal consumption in the North/South Ireland Food Consumption Survey by Galvin et al. ${ }^{(44)}$ showed an association between increased breakfast cereal consumption and a replacement of energy from fat with energy from carbohydrates and a higher proportion of individuals achieving the dietary recommendations for total fat and carbohydrate.
McNulty et al. ${ }^{(13)}$ reported that an increased consumption of RTEBC was associated with a decreased consumption of fats and a corresponding increase in carbohydrates and starch. Other studies have demonstrated this association between breakfast cereal consumption and a replacement of food energy from fat with food energy from carbohydrate ${ }^{(15,18,19)}$.

The consumption of FF was associated with a more fibredense diet. A number of studies have reported an association between increased consumption of fortified breakfast cereals and increasing fibre intakes ${ }^{(13,19,44,45)}$. Consumption of FF was associated with higher fruit intakes in men and women. In their analysis of the North/South Ireland Food Consumption Survey, Galvin et al. (M. A. Galvin, M. Kiely and A. Flynn, unpublished results) reported that fruit was twice as likely to be consumed in men and more likely to be consumed in women who consumed a RTEBC breakfast compared with any other breakfast type. Syrette et al. ${ }^{(18)}$ showed that Australian adults who consumed breakfast cereal on a daily basis ate more fruit and vegetables than those who consumed breakfast cereals less frequently.

A higher consumption of FF was associated with increased nutrient densities for most micronutrients investigated. Galvin et al. ${ }^{(44)}$ also found an increase in nutrient densities with increased RTEBC consumption in men and women. Alexy et al. ${ }^{(46)}$ assessed the effects of added sugars and FF on nutrient densities in German children aged 2-18 years and reported that the positive effects of fortification on nutrient densities exceeded the negative effects of added sugar intake for most nutrients, in some cases even twofold. The present results showed that increasing consumption of FF was not associated with increased added sugar intake in men and women.

There was a lower prevalence of inadequate intakes of $\mathrm{Ca}$, $\mathrm{Cu}, \mathrm{Zn}$, riboflavin and vitamin $\mathrm{C}$ in both men and women and of $\mathrm{Fe}$ and folate in women with increasing level of FF consumption. In the case of riboflavin, $\mathrm{Fe}$ and folate this was largely due to the addition of micronutrients to FF; for example, riboflavin and $\mathrm{Fe}$, respectively, are added to 87 and $81 \%$ of all $\mathrm{FF}^{(6)}$. For other nutrients (for example, $\mathrm{Ca}, \mathrm{Cu}, \mathrm{Zn}$ ) this is due to increased intakes from other foods as these nutrients are

Table 4. Daily intakes of fruit, vegetables (excluding potatoes) and fruit and vegetables in Irish adults by sex and tertile of energy intake from fortified foods

(Mean values and standard deviations)

\begin{tabular}{|c|c|c|c|c|c|c|c|}
\hline \multirow{3}{*}{$\begin{array}{l}\text { Consumer } \\
\text { categories }\end{array}$} & \multirow[b]{3}{*}{ Subjects $(n)$} & \multicolumn{6}{|c|}{ Intake $(g / d)$} \\
\hline & & \multicolumn{2}{|c|}{ Fruit } & \multicolumn{2}{|c|}{ Vegetables } & \multicolumn{2}{|c|}{ Fruit and vegetables } \\
\hline & & Mean & SD & Mean & SD & Mean & SD \\
\hline \multicolumn{8}{|l|}{ Men } \\
\hline Non & 234 & $110^{\mathrm{a}}$ & 138 & 147 & 77 & $256^{\mathrm{a}}$ & 170 \\
\hline Low & 143 & $107^{\mathrm{a}}$ & 111 & 149 & 83 & $257^{\mathrm{a}}$ & 156 \\
\hline Medium & 142 & $140^{\mathrm{a}}$ & 147 & 141 & 76 & $281^{\mathrm{a}}$ & 188 \\
\hline High & 143 & $189^{b}$ & 180 & 159 & 77 & $348^{\mathrm{b}}$ & 214 \\
\hline \multicolumn{8}{|l|}{ Women } \\
\hline Non & 232 & $116^{a}$ & 135 & 129 & 65 & $245^{a}$ & 174 \\
\hline Low & 161 & $132^{\mathrm{a}, \mathrm{b}}$ & 123 & 137 & 64 & $269^{a, b}$ & 151 \\
\hline Medium & 162 & $151^{\mathrm{a}, \mathrm{b}}$ & 120 & 140 & 75 & $291^{a, b}$ & 164 \\
\hline High & 162 & $169^{b}$ & 158 & 125 & 68 & $293^{\mathrm{b}}$ & 187 \\
\hline
\end{tabular}

${ }^{\mathrm{a}, \mathrm{b}}$ Mean values within a column with unlike superscript letters were significantly different between categories of fortified food consumers in men and women $(P<0.05)$. 
Table 5. Daily intake of food ${ }^{*}$ sodium and salt and percentage contribution of fortified foods (FF) to intakes by sex and tertile of energy intake from FF (Mean values and standard deviations)

\begin{tabular}{|c|c|c|c|c|c|c|c|c|c|}
\hline \multirow{2}{*}{$\begin{array}{l}\text { Consumer } \\
\text { categories }\end{array}$} & \multirow[b]{2}{*}{ Subjects $(n)$} & \multicolumn{2}{|c|}{$\mathrm{Na}(\mathrm{g})$} & \multicolumn{2}{|c|}{$\mathrm{Na}(\mathrm{g} / 10 \mathrm{MJ})$} & \multicolumn{2}{|c|}{ Salt (g) } & \multicolumn{2}{|c|}{$\begin{array}{l}\text { Percentage contri- } \\
\text { bution of FF to Na } \\
\text { intakes }\end{array}$} \\
\hline & & Mean & SD & Mean & SD & Mean & SD & Mean & SD \\
\hline \multicolumn{10}{|l|}{ Men } \\
\hline Non & 234 & $3 \cdot 3^{a}$ & $1 \cdot 2$ & $3.1^{a}$ & 0.7 & $8 \cdot 4^{\mathrm{a}}$ & 2.9 & & \\
\hline Low & 143 & $3.5^{\mathrm{a}}$ & $1 \cdot 1$ & $3 \cdot 3^{\mathrm{b}}$ & 0.6 & $8.7^{a}$ & $2 \cdot 8$ & $1.5^{\mathrm{a}}$ & 1.7 \\
\hline Medium & 142 & $3 \cdot 4^{\mathrm{a}}$ & 1.0 & $3 \cdot 2^{a, b}$ & 0.7 & $8 \cdot 5^{\mathrm{a}}$ & $2 \cdot 4$ & $3 \cdot 8^{\mathrm{b}}$ & 1.7 \\
\hline High & 143 & $4.1^{b}$ & 1.0 & $3 \cdot 3^{\mathrm{b}}$ & 0.5 & $10 \cdot 1^{b}$ & $2 \cdot 6$ & $5 \cdot 4^{c}$ & $3 \cdot 2$ \\
\hline \multicolumn{10}{|l|}{ Women } \\
\hline Non & 232 & $2 \cdot 3^{\mathrm{a}}$ & 0.6 & $3 \cdot 2^{\mathrm{a}}$ & 0.6 & $5 \cdot 8^{\mathrm{a}}$ & 1.6 & & \\
\hline Low & 161 & $2 \cdot 5^{\mathrm{b}, \mathrm{c}}$ & 0.7 & $3 \cdot 3^{a, b}$ & 0.7 & $6 \cdot 4^{\mathrm{b}, \mathrm{c}}$ & 1.8 & $1 \cdot 6^{\mathrm{a}}$ & 2.5 \\
\hline Medium & 162 & $2 \cdot 5^{\mathrm{a}, \mathrm{b}}$ & 0.7 & $3 \cdot 3^{a, b}$ & 0.6 & $6 \cdot 2^{a, b}$ & 1.6 & $3.4^{\mathrm{b}}$ & 3.5 \\
\hline High & 162 & $2 \cdot 7^{\mathrm{c}}$ & 0.7 & $3 \cdot 4^{\mathrm{b}}$ & 0.6 & $6 \cdot 7^{\mathrm{c}}$ & 1.8 & $5 \cdot 6^{c}$ & $5 \cdot 0$ \\
\hline
\end{tabular}

${ }_{\mathrm{a}, \mathrm{b}, \mathrm{c}}$ Mean values within a column with unlike superscript letters were significantly different between categories of fortified food consumers in men and women $(P<0 \cdot 05)$.

${ }^{*}$ Excluding $\mathrm{Na} /$ salt added at the table or in cooking.

either not added to FF or added to only few products. In the case of $\mathrm{Ca}$, the higher intakes and the lower prevalence of inadequacy of $\mathrm{Ca}$ intakes associated with higher FF consumption appears to be due largely to the addition of milk to cereals. It has been estimated that on average, an additional $98 \mathrm{~g}$ milk was consumed at a breakfast that contained a RTEBC compared with a breakfast that did not ${ }^{(47)}$. Vitamin $\mathrm{C}$ was added to $15 \%$ of all $\mathrm{FF}$ and therefore the higher intakes and lower prevalence of inadequate intakes can be attributed in part to fortification and also to higher intakes of other foods (for example, fruit).

Berner et al. ${ }^{(8)}$ reported on the contribution of voluntary fortification to vitamin and mineral intakes in the USA between 1989 and 1991. For those aged $>1$ year, and excluding intakes from nutritional supplements, fortification increased the median intakes of vitamin A $(21 \%)$, vitamin C (24\%), thiamin $(12 \%)$, riboflavin $(11 \%)$, niacin $(12 \%)$, folate $(23 \%), \mathrm{Fe}(14 \%)$ and $\mathrm{Zn}(6 \%)$, but did not affect intake of $\mathrm{Ca}$. Although the effect of fortification on adequacy of nutrient intakes was not examined, in many cases the added nutrients boosted the 25th percentile or median intakes from below to above the RDA.

Sichert-Hellert et al. ${ }^{(7)}$ investigated 10-year trends (1987-96) in vitamin and mineral intakes from FF in children aged 2-13 years in Germany. Over this period, the percentage contribution of $\mathrm{FF}$ to total intakes of vitamins $\mathrm{B}_{1}, \mathrm{~B}_{2}$ and $\mathrm{B}_{6}$, folate, vitamin $C$ and niacin increased from $8-19 \%$ in 1987 to $20-32 \%$ in 1995 . There was little change in the contribution to vitamin $\mathrm{E}$ intake (about 27-30\%). A follow-up study showed that the contribution of FF to micronutrient intakes reached a plateau or decreased between 1994-6 and 2000 ${ }^{(48)}$.

Previous studies have demonstrated the positive impact of fortified breakfast cereals on micronutrient intake in the diet of adults ${ }^{(11)}$ and children ${ }^{(13,15)}$. Interventions which have examined the impact of milk fortified with vitamin $\mathrm{D}^{(49,50)}$ have produced favourable changes in the serum concentrations of 25-hydroxyvitamin $\mathrm{D}(25(\mathrm{OH}) \mathrm{D})$ and have helped to reduce the seasonal decline in serum $25(\mathrm{OH}) \mathrm{D}$ by greater than $50 \%(49)$

Hannon et al. ${ }^{(6)}$ have previously shown that FF consumption in the North/South Ireland Food Consumption Survey was not associated with an increased risk of adverse effects for any micronutrient. Small proportions $(0 \cdot 1-2 \cdot 2 \%)$ of FF consumers has MDI of folic acid, vitamin $\mathrm{B}_{6}$, retinol, $\mathrm{Ca}$, $\mathrm{Zn}$ and vitamin $\mathrm{E}$ that exceeded the tolerable upper intake level but this was mainly associated with the use of nutritional supplements or, in the case of retinol, of high liver consumption and was not affected by fortification, which contributed only small amounts to the intakes of these micronutrients relative to their upper intake level.

The present study also analysed whether there was an association between FF consumption and lifestyle factors such as alcohol intake and smoking status. Higher FF consumption (compared with non-consumers) was associated with lower alcohol intake and lower likelihood of smoking in men and women.

Salt intake from food (excluding salt added in cooking and at table) exceeded the recommendation for total salt

Table 6. Irish adults with intakes of alcohol below the recommended maximum weekly intake levels by sex and tertile of energy intake from fortified foods

(Percentages)

\begin{tabular}{|c|c|c|c|c|c|c|c|c|}
\hline \multirow[b]{2}{*}{ Consumer categories... } & \multicolumn{4}{|c|}{ Men $(n$ 605) } & \multicolumn{4}{|c|}{ Women ( $n$ 703) } \\
\hline & $\begin{array}{c}\text { Non } \\
(n 231)\end{array}$ & $\begin{array}{l}\text { Low } \\
(n 134)\end{array}$ & $\begin{array}{c}\text { Medium } \\
(n \text { 144) }\end{array}$ & $\begin{array}{l}\text { High } \\
(n \text { 141) }\end{array}$ & $\begin{array}{l}\text { Non } \\
(n \text { 230) }\end{array}$ & $\begin{array}{c}\text { Low } \\
(n 158)\end{array}$ & $\begin{array}{c}\text { Medium } \\
(n \text { 159) }\end{array}$ & $\begin{array}{c}\text { High } \\
(n 156)\end{array}$ \\
\hline Intake below recommended maximum weekly intake* & $63 \cdot 2^{a}$ & $65 \cdot 7^{\mathrm{a}, \mathrm{b}}$ & $71 \cdot 5^{a, b}$ & $75 \cdot 2^{\mathrm{b}}$ & $81 \cdot 7^{\mathrm{a}, \mathrm{b}}$ & $74 \cdot 0^{\mathrm{a}}$ & $85 \cdot 5^{\mathrm{b}}$ & $87 \cdot 2^{\mathrm{b}}$ \\
\hline
\end{tabular}

${ }_{\mathrm{a}, \mathrm{b}}$ Values with unlike superscript letters were significantly different between categories of fortified food consumers in men and women $(P<0.05)$.

*Men, 21 units; women, 14 units; Department of Health and Children ${ }^{(40)}$ 
Table 7. Daily intake of micronutrients (from all sources including supplements) per $10 \mathrm{MJ}$ total energy by sex and tertile of energy intake from fortified foods

(Mean values and standard deviations)

\begin{tabular}{|c|c|c|c|c|c|c|c|c|c|c|c|c|c|c|c|c|}
\hline \multirow{3}{*}{$\begin{array}{l}\text { Consumer categories... } \\
\text { Nutrient }\end{array}$} & \multicolumn{8}{|c|}{ Men } & \multicolumn{8}{|c|}{ Women } \\
\hline & \multicolumn{2}{|c|}{ Non (n 234) } & \multicolumn{2}{|c|}{ Low (n 143) } & \multicolumn{2}{|c|}{ Medium ( $n$ 142) } & \multicolumn{2}{|c|}{ High ( $n$ 142) } & \multicolumn{2}{|c|}{ Non (n 232) } & \multicolumn{2}{|c|}{ Low (n 161) } & \multicolumn{2}{|c|}{ Medium $(n 162)$} & \multicolumn{2}{|c|}{ High (n 162) } \\
\hline & Mean & SD & Mean & SD & Mean & SD & Mean & SD & Mean & SD & Mean & SD & Mean & SD & Mean & SD \\
\hline $\mathrm{Mg}(\mathrm{mg})$ & 325 & 86 & 323 & 69 & 325 & 129 & 324 & 62 & $326^{a}$ & 87 & $333^{a}$ & 76 & $338^{a, b}$ & 76 & $358^{\mathrm{b}}$ & 101 \\
\hline$P(\mathrm{mg})$ & 1489 & 228 & 1516 & 230 & 1502 & 246 & 1507 & 215 & $1474^{\mathrm{a}}$ & 279 & $1509^{a, b}$ & 275 & $1572^{b, c}$ & 277 & $1609^{c}$ & 301 \\
\hline $\mathrm{Fe}(\mathrm{mg})$ & $12 \cdot 5^{\mathrm{a}}$ & 4.1 & $13 \cdot 0^{\mathrm{a}}$ & $5 \cdot 1$ & $13 \cdot 1^{\mathrm{a}}$ & 3.5 & $15 \cdot 4^{\mathrm{b}}$ & 3.9 & $15 \cdot 8^{\mathrm{a}}$ & $22 \cdot 3$ & $15 \cdot 8^{\mathrm{a}}$ & 15.4 & $19 \cdot 7^{a, b}$ & 23.1 & $24 \cdot 6^{\mathrm{b}}$ & 36.0 \\
\hline Riboflavin (mg) & $1.8^{\mathrm{a}}$ & 0.8 & $1.9^{\mathrm{a}}$ & 0.7 & $2 \cdot 1^{\mathrm{a}}$ & $1 \cdot 1$ & $2 \cdot 4^{\mathrm{b}}$ & 1.7 & 2.4 & $4 \cdot 1$ & $2 \cdot 2$ & $2 \cdot 3$ & 3.0 & 5.7 & 3.0 & 1.5 \\
\hline Niacin (mg) & 44.4 & $11 \cdot 1$ & 45.5 & $10 \cdot 1$ & $46 \cdot 3$ & 11.8 & $46 \cdot 3$ & $9 \cdot 2$ & $44 \cdot 0^{a, b}$ & $13 \cdot 3$ & $44 \cdot 2^{\mathrm{a}, \mathrm{b}}$ & 13.9 & $48.5^{\mathrm{b}, \mathrm{c}}$ & 14.8 & $50 \cdot 8^{\mathrm{C}}$ & 13.0 \\
\hline Folate $(\mu \mathrm{g})$ & $291^{a}$ & 123 & $293^{a}$ & 90 & $315^{a}$ & 92 & $364^{\mathrm{b}}$ & 111 & $291^{\mathrm{a}}$ & 144 & $313^{a}$ & 132 & $369^{\mathrm{b}}$ & 149 & $461^{\mathrm{b}}$ & 278 \\
\hline
\end{tabular}

a,b,c Mean values within a row with unlike superscript letters were significantly different between categories of fortified food consumers in men and women $(P<0.05)$.

Table 8. Men and women with mean daily intakes of micronutrients (from all sources including supplements) below the average requirement (AR) by sex and tertile of energy intake from fortified foods (Percentages)

\begin{tabular}{|c|c|c|c|c|c|c|c|c|c|}
\hline \multirow[b]{2}{*}{$\begin{array}{l}\text { Consumer categories... } \\
\text { Nutrient }\end{array}$} & \multirow[b]{2}{*}{$A R^{*}$} & \multicolumn{4}{|c|}{ Men } & \multicolumn{4}{|c|}{ Women } \\
\hline & & $\begin{array}{c}\text { Non } \\
(n \text { 234) }\end{array}$ & $\begin{array}{l}\text { Low } \\
(n 143)\end{array}$ & $\begin{array}{c}\text { Medium } \\
(n 142)\end{array}$ & $\begin{array}{l}\text { High } \\
(n \text { 143) }\end{array}$ & $\begin{array}{l}\text { Non } \\
(n \text { 232) }\end{array}$ & $\begin{array}{l}\text { Low } \\
(n 161)\end{array}$ & $\begin{array}{c}\text { Medium } \\
(n 162)\end{array}$ & $\begin{array}{l}\text { High } \\
(n \text { 162) }\end{array}$ \\
\hline $\mathrm{Ca}$ & $550 \mathrm{mg}$ & $16 \cdot 7^{\mathrm{a}}$ & $9 \cdot 1^{b}$ & $12 \cdot 0^{a, b}$ & $2 \cdot 1^{\mathrm{c}}$ & $34.9^{\mathrm{a}}$ & $23.0^{\mathrm{b}}$ & $17 \cdot 3^{\mathrm{b}}$ & $11 \cdot 1^{\mathrm{C}}$ \\
\hline $\mathrm{Fe}$ & $\begin{array}{l}7 \mathrm{mg} \text { (women } 18-50 \text { years } \\
10 \mathrm{mg} \text {, women } 51-64 \text { years } 6 \mathrm{mg} \text { ) }\end{array}$ & $4 \cdot 3^{\mathrm{a}}$ & $2 \cdot 1^{a, b}$ & $2 \cdot 1^{\mathrm{a}, \mathrm{b}}$ & $0^{\mathrm{b}}$ & $56 \cdot 9^{\mathrm{a}}$ & $47 \cdot 8^{\mathrm{b}}$ & $32 \cdot 1^{\mathrm{c}}$ & $12 \cdot 3^{\mathrm{d}}$ \\
\hline $\mathrm{Cu}$ & $0.8 \mathrm{mg}$ & $9 \cdot 0^{\mathrm{a}}$ & $11 \cdot 2^{\mathrm{a}}$ & $7 \cdot 7^{\mathrm{a}}$ & $2 \cdot 8^{\mathrm{b}}$ & $28 \cdot 4^{\mathrm{a}}$ & $21 \cdot 1^{\mathrm{a}, \mathrm{b}}$ & $26 \cdot 5^{\mathrm{a}}$ & $15 \cdot 4^{\mathrm{b}}$ \\
\hline $\mathrm{Zn}$ & $7.5 \mathrm{mg}$ (women $5.5 \mathrm{mg}$ ) & $14 \cdot 5^{\mathrm{a}, \mathrm{b}}$ & $16 \cdot 1^{\mathrm{a}}$ & $17 \cdot 6^{\mathrm{b}}$ & $4 \cdot 9^{\mathrm{c}}$ & $22 \cdot 0^{\mathrm{a}, \mathrm{b}}$ & $15 \cdot 5^{\mathrm{a}}$ & $15 \cdot 4^{\mathrm{b}}$ & $7 \cdot 4^{\mathrm{c}}$ \\
\hline Vitamin A & $500 \mu \mathrm{g}$ (women $400 \mu \mathrm{g}$ ) & $23 \cdot 5^{\mathrm{a}}$ & $25 \cdot 9^{\mathrm{a}}$ & $19 \cdot 0^{a, b}$ & $10 \cdot 5^{\mathrm{b}}$ & $22 \cdot 8^{\mathrm{a}}$ & $10 \cdot 6^{\mathrm{b}}$ & $13 \cdot 6^{\mathrm{b}}$ & $16 \cdot 7^{\mathrm{b}}$ \\
\hline Riboflavin & $1.3 \mathrm{mg}$ (women $1.1 \mathrm{mg}$ ) & $21 \cdot 8^{\mathrm{a}}$ & $14 \cdot 0^{\mathrm{b}}$ & $7.0^{\mathrm{b}}$ & $0.7^{\mathrm{C}}$ & $37.9^{\mathrm{a}}$ & $26 \cdot 1^{\mathrm{b}}$ & $9 \cdot 3^{\mathrm{C}}$ & $1 \cdot 2^{\mathrm{d}}$ \\
\hline Total folate & $140 \mu \mathrm{g}$ & $5 \cdot 1^{\mathrm{a}}$ & $1 \cdot 4^{\mathrm{a}, \mathrm{b}}$ & $0.7^{\mathrm{b}}$ & $0^{\mathrm{b}}$ & $20 \cdot 7^{\mathrm{a}}$ & $6 \cdot 2^{\mathrm{b}}$ & $3.1^{\mathrm{b}}$ & $0.6^{c}$ \\
\hline Vitamin C & $30 \mathrm{mg}$ & $8 \cdot 5^{\mathrm{a}, \mathrm{b}}$ & $11.9^{\mathrm{a}}$ & $8.5^{\mathrm{a}}$ & $3.5^{\mathrm{b}}$ & $17 \cdot 2^{\mathrm{a}}$ & $6 \cdot 8^{\mathrm{b}}$ & $4 \cdot 3^{\mathrm{c}}$ & $5 \cdot 6^{\mathrm{d}}$ \\
\hline
\end{tabular}

a,b,c,d Values within a row with unlike superscript letters were significantly different between categories of fortified food consumers in men and women $(P<0.05)$.

Report of the Scientific Committee for Food ${ }^{(43)}$ 
of $6 \mathrm{~g} / \mathrm{d}^{(51)}$. Intakes of salt and $\mathrm{Na}(\mathrm{g} / \mathrm{d}$ and $\mathrm{g} / \mathrm{MJ}$ per $\mathrm{d})$ were significantly higher $(P<0.05)$ in high consumers of fortified foods in comparison with non-consumers. However, when adjusted for energy intake, $\mathrm{Na}$ intake did not increase with level of FF consumption, indicating that the observed increases in salt intake with increasing level of FF consumption are related to increasing intake of food energy. The percentage contribution of FF to $\mathrm{Na}$ intakes in high consumers of FF was $5.4-5.6 \%$, which is less than their contribution to energy $(7 \cdot 0-9.3 \%)$. This indicates that FF are a relatively minor source of dietary salt, even among high FF consumers, and that the higher intake of salt in high consumers of FF is associated mainly with non-fortified foods.

In conclusion, FF consumption was associated with higher fruit intakes, lower intakes (percentage food energy) of total fat and saturated fat (women only) and higher intakes of total carbohydrate, total sugars (but not added sugars) and starch, a more micronutrient-dense diet and a reduced prevalence of dietary inadequacies of $\mathrm{Ca}, \mathrm{Fe}$, riboflavin and folate, particularly in women. The improvement in dietary quality is partly due to the contribution of FF to the diet but also partly due to differences in patterns of consumption of other foods which have yet to be analysed. A higher FF consumption was associated with a lower alcohol intake and a lower likelihood of smoking in men and women. Thus, it appears that FF consumption is a marker of both better dietary quality and healthy lifestyle behaviours.

\section{Acknowledgements}

The present study was funded by the Irish Government under the National Development Plan 2000-2006.

T. J. and E. H. contributed to the design, execution and analysis of the study and writing of the manuscript. M. K. and A. F. contributed to the design and analysis of the study and writing of the manuscript.

A. F. is nutrition advisor to Kraft Foods and a member of the ILSI (Europe) scientific working group. T. J., E. M. H. and M. K. have no conflicts to declare.

\section{References}

1. British Nutrition Foundation (1994) Food Fortification. Briefing Paper. London: British Nutrition Foundation.

2. Richardson DP (1997) Symposium on 'Food industry, nutrition and public health'. The addition of nutrients to foods. Proc Nutr Soc 56, 807-825.

3. Hannon EM, Kiely M, Harrington KE, Robson PJ, Strain JJ \& Flynn A (2001) The North/South Ireland Food Consumption Survey: mineral intakes in 18-64-year-old adults. Public Health Nutr 4, 1081-1088.

4. European Commission (2006) Regulation (EC) no. 1925/2006 of the European Parliament and of the Council of 20 December 2006 on the addition of vitamins and minerals and of certain other substances to foods. http://eur-lex.europa.eu/LexUriServ/ LexUriServ.do?uri = OJ:L:2006:404:0026:0038:EN:PDF

5. Hannon EM, Kiely M \& Flynn A (2001) The impact of fortification on micronutrient intakes in Irish adults. Proc Nutr Soc 60, $151 \mathrm{~A}$.
6. Hannon EM, Kiely M \& Flynn A (2007) The impact of fortification on micronutrient intakes in Irish adults. Br J Nutr 97, $1177-1186$.

7. Sichert-Hellert W, Kersting M, Alexy U \& Manz F (2000) Tenyear trends in vitamin and mineral intake from fortified food in German children and adolescents. Eur J Clin Nutr 54, 81-86.

8. Berner LA, Clydesdale FM \& Douglass JS (2001) Fortification contributed greatly to vitamin and mineral intakes in the United States, 1989-1991. J Nutr 131, 2177-2183.

9. Crawley HF (1993) The role of breakfast cereals in the diets of 16-17-year-old teenagers in Britain. J Hum Nutr Diet 6, $205-216$

10. Sommerville J \& O'Reagan M (1993) The contribution of breakfast to micronutrient adequacy of the Irish diet. $J$ Hum Nutr Diet 6, 223-228.

11. McNulty H, Eaton-Evans J, Woulahan G \& Strain JJ (1994) The effect of fortification on daily micronutrient intakes of breakfast cereal consumers in Great Britain. Proc Nutr Soc 53, 143A.

12. Gibson SA \& O'Sullivan KR (1995) Breakfast cereal consumption patterns and nutrient intakes of British schoolchildren. $J R$ Soc Health 115, 366-370.

13. McNulty H, Eaton-Evans J, Cran G, Woulahan G, Boreham C, Savage JM, Fletcher R \& Strain JJ (1996) Nutrient intakes and impact of fortified breakfast cereals in schoolchildren. Arch Dis Child 75, 474-481.

14. Ruxton CH, O'Sullivan KR, Kirk TR, Belton NR \& Holmes MA (1996) The contribution of breakfast to the diets of a sample of 136 primary-schoolchildren in Edinburgh. Br J Nutr 75, 419-431.

15. Ortega RM, Requejo AM, Redondo R, Lopez-Sobaler AM, Andres P, Ortega A, Gaspar MJ, Quintas E \& Navia B (1996) Influence of the intake of fortified breakfast cereals on dietary habits and nutritional status of Spanish schoolchildren. Ann Nutr Metab 40, 146-156.

16. Preziosi P, Galan P, Deheeger M, Yacoub N, Drewnowski A \& Hercberg S (1999) Breakfast type, daily nutrient intakes and vitamin and mineral status of French children, adolescents and adults. J Am Coll Nutr 18, 171-178.

17. Morgan K \& Zabik ME (1984) The influence of ready-to-eat cereal consumption at breakfast on nutrient intakes of individuals 62 years and older. $J$ Am Coll Nutr 3, 27-44.

18. Syrette JA, Baghurst KI \& Record SJ (1990) Breakfast cereals - patterns of consumption and nutritional value of regular usage. Food Aust 42, 568-573.

19. Bertrais S, Polo Luque ML, Preziosi P, Fieux B, Torra de Flot M, Galan P \& Hercberg S (2000) Contribution of ready-to-eat cereals to nutrition intakes in French adults and relations with corpulence. Ann Nutr Metab 44, 249-255.

20. Nicklas TA, Myers L \& Berenson GS (1994) Impact of readyto-eat cereal consumption on total dietary intake of children: the Bogalusa Heart Study. J Am Diet Assoc 94, 316-318.

21. Suojanen A, Raulio S \& Ovaskainen ML (2002) Liberal fortification of foods: the risks. A study relating to Finland. J Epidemiol Community Health 56, 259-264.

22. Meltzer HM \& Alexander J (2001), Addition of Vitamins and Minerals. A Discussion Paper on Health Risks Related to Foods and Food Supplements, TemaNord: 519. Copenhagen, Denmark: Nordic Council of Ministers.

23. Meltzer HE, Aro A, Andersen NL, Koch B \& Alexander J (2003) Risk analysis applied to food fortification. Public Health Nutr 6, 281-290.

24. Irish Universities Nutrition Alliance (2001) North/South Ireland Food Consumption Survey. Summary Report. Dublin, Republic of Ireland: Food Safety Promotion Board.

25. Irish Universities Nutrition Alliance (2005) National Children's Food Survey. Main Report. http://www.iuna.net (accessed June 2007). 
26. Harrington KE, Robson PJ, Kiely M, Livingstone MBE, Lambe J \& Gibney MJ (2001) The North/South Ireland Food Consumption Survey: survey design and methodology. Public Health Nutr 4, 1037-1042.

27. Kiely M, Harrington K, Robson PR, Flynn A \& Cran G (2001) Sampling description and procedures used to conduct the North/ South Ireland Food Consumption Survey. Public Health Nutr 4, $1029-1035$

28. Holland B, Welch AA, Unwin ID, Buss DH, Paul AA \& Southgate DAT (1995) McCance and Widdowson's The Composition of Foods, 5th ed. Cambridge: Royal Society of Chemistry.

29. Holland B, Unwin ID \& Buss DH (1988) Cereals and Cereal Products. Third Supplement to McCance and Widdowson's The Composition of Foods, 4th ed. Nottingham: Royal Society of Chemistry.

30. Holland B, Unwin ID \& Buss DH (1989) Milk Products and Eggs. Fourth Supplement to McCance and Widdowson's The Composition of Foods, 4th ed. Cambridge: Royal Society of Chemistry.

31. Holland B, Unwin ID \& Buss DH (1991) Vegetables, Herbs and Spices. Fifth Supplement to McCance and Widdowson's The Composition of Foods, 4th ed. Cambridge: Royal Society of Chemistry.

32. Holland B, Unwin ID \& Buss DH (1992) Fruit and Nuts. First Supplement to McCance and Widdowson's The Composition of Foods, 5th ed. Royal Society of Chemistry and Ministry of Agriculture, Fisheries and Food. Cambridge: Royal Society of Chemistry.

33. Holland B, Brown J \& Buss DH (1993) Fish and Fish Products. Third Supplement to McCance and Widdowson's The Composition of Foods, 5th ed. Cambridge: Royal Society of Chemistry.

34. Chan W, Brown J \& Buss DH (1994) Miscellaneous Foods. Fourth Supplement to McCance and Widdowson's The Composition of Foods. Cambridge: Royal Society of Chemistry.

35. Chan W, Brown J, Lee SM \& Buss DH (1995) Meat, Poultry and Game. Fifth Supplement to McCance and Widdowson's The Composition of Foods. Cambridge: Royal Society of Chemistry.

36. Chan W, Brown J, Church SM \& Buss DH (1996) Meat Products and Dishes. Sixth Supplement to the Fifth Edition of McCance and Widdowson's The Composition of Foods. Cambridge: Royal Society of Chemistry.

37. Holland B, Welch AA \& Buss DH (1996) Vegetable Dishes. Second Supplement to McCance and Widdowson's The Composition of Foods, 5th ed. Cambridge: Royal Society of Chemistry.

38. Central Statistics Office (1998) Census 1996. Volume 7. Occupations. Dublin, Republic of Ireland: Central Statistics Office.
39. Institute of Medicine of the National Academics (2002) Dietary Reference Intakes for Energy, Carbohydrate, Fiber, Fat, Fatty Acids, Cholesterol, Protein and Amino Acids. Washington, DC: National Academies Press.

40. Department of Health and Children (1995) A Health Promotion Strategy: Making the Healthier Choice the Easier Choice. Dublin, Republic of Ireland: Department of Health and Children.

41. McGowan MJ, Harrington KE, Kiely M, Robson PJ, Livingston MBE \& Gibney MJ (2001) An evaluation of energy intakes and the ratio of energy intake to estimated basal metabolic rate (EI/ $\left.\mathrm{BMR}_{\text {est }}\right)$ in the North/South Ireland Food Consumption Survey. Public Health Nutr 4, 1043-1050.

42. Black AE (2000) Critical evaluation of energy intake using the Goldberg cut-off for energy intake: basal metabolic rate. A practical guide to its calculation, use and limitations. Int $J$ Obes Relat Metab Disord 24, 1119-1130.

43. Scientific Committee on Food (1993) Nutrient and Energy Intakes for the European Community. Reports of the Scientific Committee for Food, 31st Series. Luxembourg: Office for Official Publications of the European Communities.

44. Galvin MA, Kiely M \& Flynn A (2003) Impact of ready-to-eat breakfast cereal (RTEBC) consumption on adequacy of micronutrient intakes and compliance with dietary recommendations in Irish adults. Public Health Nutr 6, 351-363.

45. Zabik ME (1987) Impact of ready-to-eat cereal consumption on nutrient intake. Cereal Foods World 32, 234-239.

46. Alexy U, Sichert-Hellert W \& Kersting M (2002) Fortification masks nutrient dilution due to added sugars in the diet of children and adolescents. J Nutr 132, 2785-2791.

47. Galvin MA, Kiely M \& Flynn A (2001) The contribution of ready-to-eat breakfast cereals to nutrient intake in Irish adults. Proc Nutr Soc 60, 151A.

48. Sichert-Hellert W, Kersting M \& Manz F (2001) Changes in time-trends of nutrient intake from fortified and non-fortified food in German children and adolescents - 15 year results of the DONALD study. Eur J Nutr 40, 49-55.

49. McKenna MJ, Freaney R, Byrne P, McBrinn Y, Murray B, Kelly M, Donne B \& O'Brien M (1995) Safety and efficacy of increasing wintertime vitamin $\mathrm{D}$ and calcium intake by milk fortification. $Q J$ Med $\mathbf{8 8}, 895-898$.

50. Keane EM, Healy M, O'Moore R, Coakley D \& Walsh JB (1998) Vitamin D-fortified liquid milk: benefits for the elderly community-based population. Calcif Tissue Int 62, 300-302.

51. Food Safety Authority of Ireland (2005) Salt and Health: Review of the Scientific Evidence and Recommendation for Public Policy in Ireland. Dublin, Republic of Ireland: Food Safety Authority of Ireland. 